\title{
A Randomized Controlled Comparison of Effects of Three Different Agents Used for Local Anesthesia in Transrectal Ultrasound- Guided Prostate Biopsy
}

\author{
Transrektal Ultrason Kılavuzluğundaki Prostat Biyopsisinde Kullanılan Üç Farklı Anestezik \\ Ajanın Etkinliklerinin Randomize Kontrollü Karşılaştıııması
}

\author{
Sinan Avcı, Sedat Öner, Volkan Çağlayan, Efe Önen, Mustafa Murat Aydos, Murat Demirbaş \\ Yüksek Ihtisas Training and Research Hospital, Clinic of Urology, Bursa, Turkiye
}

\begin{abstract}
What's known on the subject? and What does the study add?
In many studies it has been shown that administration of local anesthesia is effective to decrease the pain in the prostate biopsy procedure. In contrast to this, there are limited number of studies that evaluate pain associated with the injection of these agents, their specific advantages and the duration of their effects. Therefore, we evaluated three different anesthetic agents, specifically, on their effectiveness in pain management during prostate biopsy in regard to these aspects. We used lidocaine which is a short-acting anesthetic commonly used in literature, as well as bupivacaine and levobupivacaine which both are long-acting anesthetic agents.
\end{abstract}

\begin{abstract}
Objective: To evaluate the effects of three different local anesthetic agents in patients who underwent Transrectal ultrasoun guided prostate needle biopsy.

Materials and Methods: One hundred and sixty patients who were admitted to our clinic between January 2012 and May 2012 for prostate biopsy were divided into 4 groups: no anesthesia-administered group (group 1), lidocaine-administered group (group 2), levobupivacaine-administered group (group 3) and bupivacaine-administered group (group 4). Pain intensity was evaluated in each group using the visual analog scale (VAS): during administration of local anesthetic (VAS 1), during the biopsy (VAS 2), just after the biopsy (VAS 3) and one hour after the biopsy (VAS 4).

Results: There was not any significant difference among the groups in terms of VAS $1(p=0.152)$. Pain scores were significantly lower during biopsy (VAS 2) in groups 1, 2 and 3 compared to that in group $1(p=0.001, p=0.005$ and $p=0.007$, respectively). VAS 3 scores were significantly lower in group 2 and group 3 compared to group 1 while no difference was found in group 4 ( $p=0.003, p=0.032$, and $p=0.136$, respectively). VAS 4 scores were significantly lower only in group 3 compared to group 1 ( $p=0.001)$.

Conclusions: It was observed that all the three local anesthetics effectively diminished pain during prostate biopsy. However, we found that levobupivacaine, which improved pain scores in all steps of pain evaluation compared to the control group, was relatively superior for pain management in the transrectal biopsy setting.
\end{abstract}

Keywords: Pain, Analgesia, Anesthesia, Periprostatic nerve blockage, Prostate biopsy, Transrectal ultrasonography

Öz

Amaç: Bu çalışmada transrektal ultrason kılavuzluğunda prostat biyopsisi alınan hastalarda kullandığımız üç farklı lokal anestezik ajanın etkilerini değerlendirdik.

Gereç ve Yöntem: Ocak 2012-Mayıs 2012 tarihleri arasında kliniğimizde prostat biyopsisi uygulanan 160 hasta dört gruba ayrıldı; anestezi kullanılmayan grup (grup 1), lidokain kullanılan grup (grup 2), bupivakain kullanılan grup (grup 3) ve bupivakain kullanılan grup (grup 4). Her grupta ağrı skorları vizüel analog skala (VAS) kullanılarak ölçüldü; lokal anestezik ajanın uygulanması sırasındaki ağrı skoru (VAS 1), biyopsi sırasındaki ağrı skoru (VAS 2), biyopsiden hemen sonraki ağrı skoru (VAS 3) ve biyopsiden bir saat sonraki ağrı skoru (VAS 4).

Correspondence: Sinan Avcı MD, Yüksek intisas Training and Research Hospital, Clinic of Urology, Bursa, Turkiye E-mail: sinavci@yahoo.com ORCID-ID: orcid.org/0000-0002-3354-5352

Received: 07.09.2017 Accepted: 16.11.2017

Cite this article as: Avcı S, Öner S, Çağlayan V, Önen E, Aydos MM, Demirbaş M. A Randomized Controlled Comparison of Effects of Three Different Agents Used for Local Anesthesia in Transrectal Ultrasound-Guided Prostate Biopsy. J Urol Surg 2018;5(1):30-36

बCopyright 2018 by the Association of Urological Surgery / Journal of Urological Surgery published by Galenos Publishing House. 
Bulgular: VAS 1 için gruplar arasında anlamlı bir fark bulunmadı $(p=0,152)$. VAS 2 için anestezi uygulanan her 3 gruptaki ağrı skorları anestezi uygulanmayan gruba göre anlamlı olarak düşüktü (p değerleri sırasıyla: 0,001, 0,005,0,007). VAS 3 skorları grup 2 ve grup 3 'te anestezi uygulanmayan gruba göre anlamlı olarak düşükken grup 4 için anlamlı bir fark saptanmadı (p değerleri sırasıyla: 0,003, 0,032, 0,136). VAS 4 ağrı skorları anestezi uygulanmayan grupla karşılaştırıldığında sadece grup 3 için anlamlı olarak düşük bulundu $(p=0,001)$.

Sonuç: Kullandığımız üç lokal anestezik ajanın da yapılan prostat biyopsileri sırasında oluşan ağrıları etkili bir şekilde azalttığı gösterilmiştir. Bununla beraber ağrının değerlendirildiği her üç aşamada da kontrol grubuna göre ağrı skorlarını anlamlı şekilde azaltan levobupivakainin bu ajnalar içerisinde bir adım öne çıktığı görülmüştür. Bu nedenle daha etkili bir ajan olarak levoupivakainin kullanımı öneriyoruz.

Anahtar Kelimeler: Ağrı, Analjezi, Anestezi, Periprostatik sinir blokajı, Prostat biyopsi, Transrektal

\section{Introduction}

Transrectal ultrasound (TRUS)-guided prostate biopsy is a standard method in the diagnosis of prostate cancer. Although minimally invasive, it is not a painless procedure $(1,2,3,4)$. Procedure-related pain especially occurs due to placement of the probe in the anal canal, movement of the probe and penetration of the needle to the prostate during biopsy (5). The recent increase in the number of diagnostic biopsies associated with widespread use of prostate-specific antigen (PSA) has enhanced the interest on studies on improving patient comfort. With prostate biopsies being performed in younger patients, the increase in the number of biopsied quadrants and the increase in the number of repeat biopsies, the importance of pain control has increased. Studies done previously for this purpose have focused on intrarectal gel instillation and periprostatic nerve blockage. Intrarectal gel instillation was not found to be effective in decreasing pain in most studies $(6,7,8,9)$. However, periprostatic nerve blockage was found to be effective in diminishing pain in many studies, as well as two meta-analyses $(10,11,12,13,14)$. It has been shown that various anesthetic agents used for periprostatic nerve blockage, such as articaine, bupivacaine, levobupivacaine, ropivacaine, lignocaine and mainly lidocaine, provide effective analgesia $(10,11,12,15,16,17)$. In contrast to this, there are limited number of studies evaluating pain associated with the injection of these agents, their specific advantages and the duration of their effects. Therefore, we evaluated three different anesthetic agents, specifically their effectiveness in pain management during prostate biopsy in regard to these aspects. In our study, we used lidocaine which is a commonly used short-acting anesthetic, as well as bupivacaine and levobupivacaine which both are long-acting anesthetic agents.

\section{Materials and Methods}

Our study group was comprised of 160 patients who underwent TRUS-guided prostate needle biopsy for suspected prostate cancer in the urology clinic at Bursa Yüksek Intisas Training and Research Hospital between January and May 2012. A prostate biopsy was warranted in case of abnormal rectal examination and/or serum PSA levels above $2.5 \mathrm{ng} / \mathrm{mL}$. Patients with acute prostatitis, prostadynia, painful conditions of prostate, rectum or anus such as anal fissure or stricture; patients with decreased pain sensation such as lower extremity paraplegia or no sensation at all; patients with hemorrhagic diathesis; patients who routinely receive analgesics, anxiolytics or narcotic drugs; patients with allergy to local anesthetics; patients who are unable to mark on the pain scale and patients who previously underwent TRUS-guided prostate biopsy were excluded from the study.

Approval was obtained from the ethics committee of our hospital for this study (Ethics Committee of Yüksek ihtisas Training and Research Hospital reg. no: 2012/9/3). All patients were informed on TRUS-guided prostate biopsy and its complications. In addition, possible complications and information about the present conditions of all patients, who did not take anesthesia and underwent periprostatic nerve blockage, were explained. Informed consents were obtained for the procedure.

Antibiotic prophylaxis was done with $500 \mathrm{mg}$ ciprofloxacin twice daily one day prior to biopsy procedure and continued for the following 4 days. An intrarectal fleet enema was applied for bowel preparation in the morning of the biopsy. Digital rectal examinations of the patients were divided as suspicious and non-suspicious. Patients with findings of hardness, nodule, irregularity and effacement of sulci, etc. were included in the suspicious group. Age, total and free PSA levels, prostate volumes and educational levels of the patients were evaluated prior to the procedure. In regard to educational level, patients were divided as 8 years of obligatory education and below or more than 8 years of obligatory education. Pathology results of the patients were recorded as either benign or malign. The patients were randomized and divided into 4 groups, each consisting of 40 patients: group 1: no analgesia or anesthesia, group 2: 2\% lidocaine injection, group 3: 0.25\% levobupivacaine injection, and group 4: 0.25\% bupivacaine injection. Anesthetic substance injection and prostate biopsy were done in the left lateral decubitus position with the hips and legs in flexion. For TRUS imaging, a 'LOGIO 100 PRO Series' ultrasound machine with a $6.5 \mathrm{MHz}$ rectal probe with a maximum diameter of 23 $\mathrm{mm}$ was used. After the probe was placed rectally, the prostate was visualized in the sagittal and transverse planes and the prostate volume was calculated automatically utilizing the 
ellipsoid formula within the ultrasound equipment. Anesthetic agents were injected using a $30 \mathrm{~cm} 18 \mathrm{G}$ spinal anesthesia needle following the placement of the TRUS probe. 5 ccs of local anesthetic was then injected in the sagittal plane between the base of the prostate and the seminal vesicle in the region where both neurovascular bundles were located. The biopsy procedure was then performed by the same physician in all patients after allowing 10 minutes for the establishment of the periprostatic nerve blockage. Biopsy samples were obtained as 12 cores, using a $30 \mathrm{~cm} 18 \mathrm{G}$ automatic biopsy needle. Since all of our patients underwent biopsy for the first time, transitional zone sampling was not performed. A visual analog scale (VAS) with $10 \mathrm{~cm}$ length was used for assessing pain. This scale reflects pain intensity from zero (0) starting point where no pain is felt to ten (10) ending point where the pain experienced so far is most severe. The physician who performed the biopsy procedure described the VAS to the patients and asked them to mark a point appropriate for the pain they felt. The distance from zero to each patient's mark for pain was measured in millimeters and the data obtained were recorded as the pain scores.

The patients were asked to assess their pain in 4 different time points during the procedure:

VAS 1: Pain score during injection of anesthetic agent.

VAS 2: Pain score during the biopsy, after first half of the procedure is completed.

VAS 3: Pain score right after the biopsy, following removal of the probe.

VAS 4: Pain score 1 hour after the biopsy.

Since no anesthetic agents were administered in group 1, pain score data for injection (VAS 1) did not exist for this group. The patients were called for follow up on the $7^{\text {th }}$ and $14^{\text {th }}$ days following the biopsy procedure and any complications were recorded.

\section{Statistical Analysis}

Non-parametric statistical tests were used for statistical analysis. For comparison of the groups, the Mann-Whitney $\mathrm{U}$ and Kruskal-
Wallis tests were used. The Wilcoxon signed-rank test was used for dependent variables, and chi-square and Fisher's exact tests were used for evaluating categorical data. Any difference with a $p$ value of $<0.05$ was considered statistically significant.

\section{Results}

Age, total and free PSA values and prostate volumes are shown in Table 1; educational levels, digital rectal examination findings and pathology results are shown in Table 2. There was not any difference among the groups in terms of these variables. Median, minimum, maximum and average values of VAS 1, VAS 2, VAS 3 and VAS 4 pain scores for all groups are shown in Table 3 . There was not any difference among the anesthetic agents for VAS $1(p=0.152)$. When the VAS 2 pain scores were evaluated, the anesthesia groups had significantly lower pain scores compared to control group. We did not observe a statistically significant difference in pain alleviation between different local anesthesia agents during needle biopsy (Table 4). VAS 3 pain scores were significantly lower in the lidocaine and levobupivacaine groups compared to the control group, while there was no significant difference for bupivacaine. VAS 3 scores were similar between local anesthetic-administered groups (Table 4). Interestingly, only the patients in the levobupivacaine-administered group (group 3) reported a significant alleviation of pain in the 1 hour postoperative pain assessment (VAS 4) compared to both the control group and the other two anesthetic agents-administered groups. Lidocaine and bupivacaine did not produce a significant analgesic effect 1 hour post-biopsy (Table 4). Since we did not administer a placebo in lieu of anesthesia in our control group patients, in order to evaluate the pain associated with injection of the local anesthetic agent, we compared the pain intensity during the administration of local anesthesia (VAS 1) in the anesthesia-administered groups with the pain during prostate needle biopsy in the control group (VAS 2). VAS 2 pain scores in the control group was significantly higher than VAS 1 pain scores in group 2, while there was not any significant difference between group 3 and group $4(p=0.001, p=0.148$ and $p=0.066$, respectively). We also compared VAS 1 and VAS 2 pain scores

Table 1. Median, minimum and maximum values of the age, total prostate-specific antigen, free prostate-specific antigen and prostate volumes of the patients according to groups. P values calculated with Kruskal Wallis test

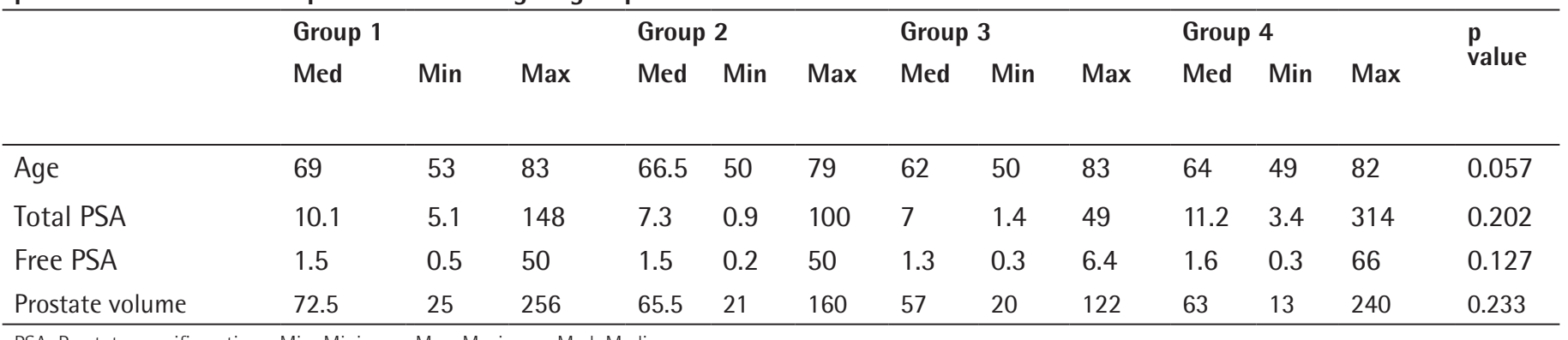

PSA: Prostate-specific antigen, Min: Minimum, Max: Maximum, Med: Median 
and observed that pain scores were not significantly different between the groups 2,3 and $4(p=0.627, p=0.116$ and $p=0.171$, respectively). As seen in Table 4, statistically significant low pain scores in all three time points were observed only in the levobupivacaine group. For lidocaine, VAS 2 and VAS 3 pain scores were significantly lower compared to the control group. In the bupivacaine group, however, only the VAS 2 time point scores were significantly lower. In evaluation of the anesthesiaadministered groups, we did not observe a statistically significant difference in VAS 2 and VAS 3 pain scores while group 3 had lower VAS 4 pain scores compared to group 2 and group 4. Neither hypertensive nor syncope episodes requiring cancellation of the procedures was observed in all patients including group 1 . The above mentioned complications did not occur also after the procedure. Rectal bleeding was seen in a total of 42 patients (10 patients in group 1, 13 patients in group 2, 9 patients in group 3, 10 patients in group 4). Hematuria was seen in a total of 11 patients (4 patients in group 1, 4 patients in group 2, 1 patient in group 3, 2 patients in group 4). Fever above $38^{\circ} \mathrm{C}$ was seen in 2 patients of group 1 and orchitis was observed in 1 patient of group 3. Pairwise comparison of the groups did not reveal any significant difference in terms of complications $(p=>0.05)$.

\section{Discussion}

TRUS-guided prostate biopsy is a routine method performed in outpatient settings for the diagnosis of prostate cancer. There are numerous studies indicating that periprostatic nerve blockage is an effective method for diminishing pain related to this procedure $(10,11,12,13,14)$. However, periprostatic infiltration of the anesthetic is not a painless procedure in itself $(1,2,3,4)$. Ashley et al. (2) reported that this was the most painful part of the procedure. In this study, pain produced by injection was higher in amplitude than the biopsy pain measured at the time when the patient was under local anesthesia. However, we believe that injection-related pain would not be the most painful part of the procedure if the pain associated with injection in this study was compared to the biopsy pain in a patient who did not receive anesthesia. Indeed, in our study, when we compared the pain intensity during injection with biopsy-related pain, we found it to be comparatively low across all anesthesia groups, statistically

Table 2. Numeric distribution of educational level, digital rectal examination finding and pathology results according to groups and $p$ values of the comparisons with chi-square test among the groups

\begin{tabular}{|c|c|c|c|c|c|c|c|}
\hline & & Group 1 & Group 2 & Group 3 & Group 4 & Total & $p$ value \\
\hline \multirow[b]{2}{*}{ Education level } & Obligatory school and below & 35 & 30 & 32 & 33 & 130 & \multirow[b]{2}{*}{0.376} \\
\hline & Above obligatory school & 5 & 10 & 8 & 7 & 30 & \\
\hline \multirow{2}{*}{$\begin{array}{l}\text { Digital rectal } \\
\text { examination finding }\end{array}$} & Non-suspicious & 18 & 25 & 25 & 19 & 87 & \multirow[b]{2}{*}{0.147} \\
\hline & Suspicious & 22 & 15 & 15 & 21 & 73 & \\
\hline \multirow{2}{*}{ Pathology result } & Malign & 7 & 8 & 10 & 8 & 33 & \multirow[t]{2}{*}{0.862} \\
\hline & Total & 40 & 40 & 40 & 40 & 160 & \\
\hline
\end{tabular}

Table 3. Median. minimum. maximum and average levels of the groups for each visual analog scale score. Values represent the distance between zero point and patient marked point as millimeters

\begin{tabular}{|c|c|c|c|c|c|c|c|c|c|c|c|c|c|c|c|c|}
\hline & \multicolumn{4}{|l|}{$\begin{array}{c}\bar{c} \\
\bar{z} \\
\overline{0} \\
0\end{array}$} & \multicolumn{4}{|l|}{ 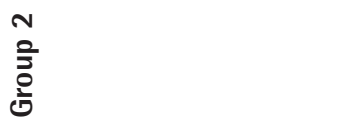 } & \multicolumn{4}{|l|}{$\begin{array}{l}\text { m } \\
\text { 을 } \\
\text { 혼 }\end{array}$} & \multicolumn{4}{|l|}{$\begin{array}{l}+ \\
\circ \\
\bar{a} \\
0 \\
0\end{array}$} \\
\hline & 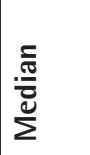 & 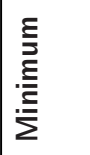 & 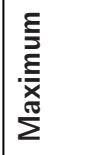 & $\frac{\bar{\pi}}{\stackrel{\Xi}{\Sigma}}$ & 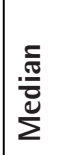 & 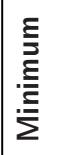 & 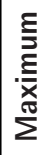 & $\frac{\text { I }}{\sum^{\frac{J}{\Sigma}}}$ & $\frac{\frac{c}{\pi}}{\frac{\pi}{\delta}}$ & 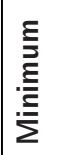 & 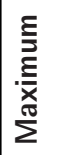 & $\frac{\bar{\Xi}}{\stackrel{\Xi}{\Sigma}}$ & $\frac{\frac{c}{\pi}}{\frac{\pi}{2}}$ & 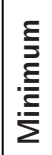 & 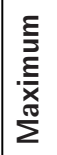 & 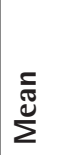 \\
\hline VAS 1 & None & None & None & None & 16.2 & 83 & 23 & 9 & 27 & 3 & 94 & 33.1 & 27 & 2 & 92 & 31.9 \\
\hline VAS 2 & 34 & 2 & 97 & 44.4 & 16 & 2 & 83 & 22.8 & 23 & 3 & 63 & 25.3 & 16 & 2 & 94 & 30.1 \\
\hline VAS 3 & 18 & 2 & 88 & 25.8 & 6 & 2 & 84 & 15.1 & 9 & 2 & 90 & 17.7 & 8 & 2 & 97 & 21.6 \\
\hline VAS 4 & 3 & 2 & 18 & 4.3 & 2 & 1 & 72 & 6 & 2 & 1 & 6 & 1.9 & 3 & 1 & 18 & 3.2 \\
\hline
\end{tabular}


Table 4. P values for pairwise comparisons of groups for each visual analog scale score

\begin{tabular}{lllllll}
\hline & p values & & & & & \\
& Group 1-2 & Group 1-3 & Group 1-4 & Group 2-3 & Group 2-4 & Group 3-4 \\
\hline VAS 2 & $<0.001$ & 0.005 & 0.007 & 0.345 & 0.470 & 0.872 \\
VAS 3 & 0.003 & 0.032 & 0.136 & 0.508 & 0.114 & 0.346 \\
VAS 4 & 0.129 & $<0.001$ & 0.550 & 0.049 & 0.233 \\
\hline
\end{tabular}

VAS: Visual analog scale

significantly so for the lidocaine group. Although we did not show a statistically significant difference for levobupivacaine and bupivacaine, average pain scores during administration of these anesthetics were almost one third lower (Table 3). When we used an evaluation similar to that in the study by Ashley et al. (2), we observed that the most painful part of the procedure was not the pain measured during injection. When we compared the pain during local anesthetic injection with the pain occurring during biopsy in the same group, pain scores were similar between the groups 2,3 and $4(p=0.627, p=0.116$, and $p=0.171$, respectively). Therefore, the pain associated with local anesthetic substance injection was only as intensive as the pain occurring during the biopsy. Moreover, local anesthetic injection is a procedure done twice (bilaterally) and it takes a relatively short time. In comparison, during the biopsy procedure, the biopsy needle is inserted into the prostate for at least 10-12 times and for a longer period compared to local anesthetic injection. Therefore, we believe that extra pain burdened on the patient by local anesthetic injection is negligible compared to gains attained by the injection. We did not find a statistically significant difference among the agents when we compared the pain occurring during injection, although the pain scores measured in the lidocaine group were lower than in the other two groups (Table 3). There are four previous studies in the literature comparing the pain produced by lidocaine injection with a placebo. While in one study, lower pain scores were obtained in the lidocaine group (5), a significant difference in pain scores was not found in these studies $(3,10,18)$. There are limited numbers of studies on this subject, but in the light of our results, we hypothesize that for the pain associated with injection, the volume effect produced by the anesthetic agent in the injection area could be more important than the type of agent used. In our study, we found that the intensity of pain occurred during the procedure was significantly lower in all the three groups that received anesthesia compared to the control group (Table 4). Our results in the lidocaine group is similar to many studies done with the same agent $(1,5,10,18,19,20,21)$. In one of the studies done with bupivacaine, Rabets et al. (22) reported that bupivacaine alone was superior to the control group while in another study, Yurdakul et al. (15) demonstrated that bupivacaine combined with lidocaine gel was superior to controls, and the results of both studies were consistent with ours. In a study by Aktoz et al. (16), levobupivacaine was superior to $50 \mathrm{mg}$ diclofenac sodium administered rectally but in this study, unlike ours, levobupivacaine was not compared with a control group. We observed that there was not a significant difference between the anesthetic agents in alleviating pain occurring during the procedure (Table 4). Yurdakul et al. (15) reported that there was not any significant difference between ropivacaine and bupivacaine combined with intrarectal lidocaine gel in decreasing biopsy-related pain. Considering this, we believe that periprostatic nerve blockage is necessary in order to decrease pain during prostate biopsy, however, agents used for this purpose do not have any superiority to each other. Although periprostatic nerve blockage was found to be an effective method in our study, consistent with literature in general, Obek et al. (19) stated that periprostatic nerve blockage combined with intrarectal lidocaine gel was more effective in decreasing pain associated with the procedure than periprostatic nerve blockage alone. They concluded that additional administration of intrarectal anesthetic gel could diminish pain resulting from probe placement. Inal et al. (23) similarly reported that in alleviating pain due to probe placement, this same combination was more effective than periprostatic nerve blockage alone. However, contrary to Obek et al. (19), they did not find any significant difference in pain that occurred during the procedure between these two groups. In our study, we believed that intrarectal analgesic gel administration would be an additional factor that could interfere with our results since we primarily aimed to compare anesthetic agents with each other. Similar to our study, Izol et al. (20) reported that lidocaine diminished end-of-procedure pain significantly compared to controls. While pain scores in our study were lower in the lidocaine and levobupivacaine groups compared to the control group, there was not a statistically significant difference in pain in the bupivacaine group, even though the pain scores were lower than in the controls (Table 4). When anesthetic agents were compared with each other, no single agent was observed to be superior in regard to management of end-of-procedure pain (Table 4). Keeping this information in mind, it seems that anesthetic agents are also effective in decreasing pain just at the end of the procedure. Lee-Elliott et al. (24) investigated the utility of combination of long- and short-acting agents in order to prevent the rebound effect that can be seen in the early phase after biopsy due to short-acting anesthetic agent use. In their study, they reported that a combination of bupivacaine and lidocaine was more effective in decreasing the first-hour 
pain than lidocaine only. In a study which evaluated the firsthour pain following a prostate biopsy procedure, Yurdakul et al. (15) compared the combination of two long-acting agents, bupivacaine and ropivacaine, with lidocaine gel and found that they decreased the pain effectively, even though either method was not superior. Dridi et al. (25) compared patients who received short-acting lidocaine, long-acting bupivacaine or placebo, and they found that in bupivacaine-administered patients, pain scores were lower in the $1^{\text {st }}, 2^{\text {nd }}$ and $3^{\text {rd }}$ hours, compared to both placebo and lidocaine groups. In our study, it was seen that the only agent that decreased the first-hour pain significantly compared to control group was levobupivacaine (Table 4). When we evaluate our findings alongside the aforementioned studies, we believe that a long-acting anesthetic agent should be used during early stage following biopsy in order to improve patent control.

\section{Study Limitations}

The limitation of our study was the lack of a placebo group.

\section{Conclusions}

Assessing our results in general, we observed that periprostatic nerve blockage provides effective pain control during a prostate biopsy procedure without increasing complication rates. We have shown that long-acting anesthetic agents used for this procedure decrease pain associated with the procedure as efficiently as short-acting agents, therefore, we believe there is no advantage of using short- and long-acting agents in combination. Moreover, we assume that long-acting agents could be better in controlling pain occurring after the procedure compared to short-acting agents. The use of long-acting agents for periprostatic nerve blockage therefore is recommended. In our study, where we compared two long-acting agents, it was seen that levobupivacaine, which acts better in controlling pain during the early post-procedure period, is one step ahead of the other agents. This finding seems to be consistent with those in other studies which reported that levobupivacaine caused a longer period of sensory block compared to bupivacaine $(26,27)$. Also, it has been reported that levobupivacaine had fewer adverse effects on cardiovascular function (28). Considering the results of our study along with these advantages, we believe that levobupivacaine could be a better choice for nerve blockage and recommend its use in the prostate biopsy setting.

\section{Ethics}

Ethics Committee Approval: Approval was obtained from Ethical Committee of Yüksek İhtisas Training and Research Hospital for this study (approval number: 2012/9/3).

Informed Consent: Informed consents were obtained for the procedure. All procedures performed in studies involving human participants were in accordance with the ethical standards of the institutional and/or national research committee and with the 1964 Helsinki declaration and its later amendments or comparable ethical standards.

Peer-review: Externally and internally peer-reviewed.

\section{Authorship Contributions}

Surgical and Medical Practices: S.A., V.Ç., Concept: S.A., Design: S.A., Data Collection or Processing: S.A., M.M.A., Analysis or Interpretation: S.A., S.Ö., M.D., Literature Search: S.A., E.Ö., Writing: S.A.

Conflict of Interest: No conflict of interest was declared by the authors.

Financial Disclosure: The authors declared that this study has received no financial support.

\section{References}

1. Schostak M, Christoph F, Müller M, Heicappell R, Goessl G, Staehler M, Miller K. Optimizing local anesthesia during 10-core biopsy of the prostate. Urology 2002;60:253-257.

2. Ashley RA, Inman $B A$, Routh $J C$, Krambeck $A E$, Siddiqui $S A$, Mynderse $L A$, Gettman MT, Blute ML. Preventing pain during office biopsy of the prostate. Cancer 2007;110:1708-1714.

3. Ingber MS, Ibrahim I, Turzewski C, Hollander JB, Diokno AC. Does periprostatic block reduce pain during transrectal prostate biopsy? A randomized, placebo-controlled, double-blinded study. Int Urol Nephrol 2010;42:23-27.

4. Mallick $S$, Humbert M, Braud F, Fofana M, Blanchet P. Local anesthesia before transrectal ultrasound guided prostate biopsy: comparison of 2 methods in a prospective, randomized clinical trial. J Urol 2004;171:730733.

5. Leibovici D, Zisman A, Siegel YI, Sella A, Kleinmann J, Lindner A. Local anesthesia for prostate biopsy by periprostatic lidocaine injection: a double-blind placebo controlled study. J Urol 2002;167:563-565.

6. Chang SS, Alberts G, Wells N, Smith JA Jr, Cookson MS. Intrarectal lidocaine during transrectal prostate biopsy: results of a prospective double-blind randomized trial. J Urol 2001;166:2178-2180.

7. Desgrandchamps $F$, Meria $P$, Irani J, Desgrippes A, Teillac $P$, Le Duc A. The rectal administration of lidocaine gel and tolerance of transrectal ultrasonography-guided biopsy of the prostate: a prospective randomized placebo-controlled study. BJU Int 1999;83:1007-1009.

8. Díaz Pérez GA, Meza Montoya L, Morante Deza C, Pow-Sang Godoy M, Destefano Urrutia V. Pain during transrectal ultrasound guided needle biopsy of the prostate: comparison of the use or not of lidocaine gel. Actas Urol Esp 2009;33:134-137.

9. Cevik I, Ozveri H, Dillioglugil O, Akdaş A. Lack of effect of intrarectal lidocaine for pain control during transrectal prostate biopsy: a randomized prospective study. Eur Urol 2002;42:217-220.

10. Nash PA, Bruce JE, Indudhara R, Shinohara K. Transrectal ultrasound guided prostatic nerve blockade eases systematic needle biopsy of the prostate. $J$ Urol 1996;155:607-609.

11. Soloway MS, Obek C. Periprostatic local anesthesia before ultrasound guided prostate biopsy. J Urol 2000;163:172-173. 
12. Von Knobloch R, Weber J, Varga Z, Feiber H, Heidenreich A, Hofmann R. Bilateral fine-needle administered local anaesthetic nerve block for pain control during TRUS-guided multi-core prostate biopsy: a prospective randomised trial. Eur Urol 2002;41:508-514.

13. Tiong HY, Liew LC, Samuel M, Consigliere D, Esuvaranathan K. A metaanalysis of local anesthesia for transrectal ultrasound-guided biopsy of the prostate. Prostate Cancer and Prostatic Dis 2007;10:127-136.

14. Richman JM, Carter HB, Hanna MN, Murphy JD, Rowlingson AJ, Andrews $\mathrm{RA}, \mathrm{Wu} \mathrm{CL}$. Efficacy of periprostatic local anesthetic for prostate biopsy analgesia: a meta-analysis. Urology 2006;67:1224-1228.

15. Yurdakul T, Taspinar B, Kilic O, Kilinc M, Serarslan A. Topical and long-acting local anesthetic for prostate biopsy: a prospective randomized placebocontrolled study. Urol Int 2009;83:151-154.

16. Aktoz $\mathrm{T}$, Kaplan M, Turan $\mathrm{U}$, Memis $\mathrm{D}$, Atakan IH, Inci O. Multimodal approach to management of prostate biopsy pain and effects on sexual function: efficacy of levobupivacaine adjuvant to diclofenac sodium-a prospective randomized trial. Andrologia 2010;42:35-40.

17. Kuppusamy S, Faizal N, Quek KF, Razack AH, Dublin N. The efficacy of periprostatic local anaesthetic infiltration in transrectal ultrasound biopsy of prostate: a prospective randomised control study. World J Urol 2010;28:673-676.

18. Berger AP, Frauscher $F$, Halpern EJ, Spranger $R$, Steiner $H$, Bartsch $G$, Horninger W. Periprostatic administration of local anesthesia during transrectal ultrasound-guided biopsy of the prostate: A randomized, double-blind, placebo-controlled study. Urology 2003;61:585-588.

19. Obek C, Ozkan B, Tunc B, Can G, Yalcin V, Solok V. Comparison of 3 different methods of anesthesia before transrectal prostate biopsy: a prospective randomized trial. J Urol 2004;172:502-505.

20. Izol V, Soyupak B, Seydaoglu G, Aridogan IA, Tansug Z. Three different techniques for administering analgesia during transrectal ultrasound- guided prostate biopsy: a comparative study. Int Braz J Urol 2012;38:122128.

21. Raber M, Scattoni $V$, Roscigno $M$, Deho F, Briganti $A$, Salonia A, Gallina A, Di Girolamo VD, Montorsi F, Rigatti P. Topical prilocaine-lidocaine cream combined with peripheral nerve block improves pain control in prostatic biopsy: Results from a prospective randomized trial. Eur Urol 2008;53:967975.

22. Rabets JC, Jones JS, Patel AR, Zippe CD. Bupivacaine provides rapid, effective periprostatic anesthesia for transrectal prostate biopsy. BJU Int 2004;93:1216-1217.

23. Inal G, Adsan 0, Ugurlu 0, Kaygısız O, Kosan M, Cetinkaya M. Comparison of four different anesthesia methods for relief of all pain during transrectal ultrasound-guided prostate biopsy. Int Urol Nephrol 2008;40:335-339.

24. Lee-Elliott CE, Dundas D, Patel U. Randomized trial of lidocaine vs lidocaine/ bupivacaine periprostatic injection on longitudinal pain scores after prostate biopsy. J Urol 2004;171:247-250.

25. Dridi M, Larbi H, Ghorbel J, Khouni H, Ghozzi S, Ben Rais N. 166 local anaesthesia for prostate biopsy by periprostatic infiltration: Lidocaine versus bupivacaine: A prospective, randomized, double-blind placebocontrolled study. Eur Urol Suppl 2010;9:84.

26. Kopacz DJ, Allen HW, Thompson GE. A comparison of epidural levobupivacaine $0.75 \%$ with racemic bupivacaine for lower abdominal surgery. Anest Analg 2000;90:642-648.

27. Cox CR, Checketts MR, Mackenzie N, Scott NB, Bannister J. Comparison of $\mathrm{S}(-)$-bupivacaine with racemic (RS)-bupivacaine in supraclavicular brachial plexus block. Br J Anaesth 1998;80:594-598.

28. Bardsley H, Gristwood R, Baker H, Watson N, Nimmo W. A comparison of the cardiovascular effects of levobupivacaine and rac-bupivacaine following intravenous administration to healthy volunteers. $\mathrm{Br} \mathrm{J}$ Clin Pharmacol 1998;46:245-249. 